\title{
Lucrezia Marinelli and Woman's Identity in Late Italian Renaissance
}

\author{
PRUDENCE ALLEN, $r s m$ \& FILIPPO SALVATORE
}

In this paper the Italian Humanist Lucrezia Marinelli (1571-1653) will be examined from the two complementary perspectives on her place in the late Italian Renaissance Studies and her contribution to the philosophy of woman. ${ }^{1}$ Marinelli is remarkable in both areas of intellectual history; and her relatively unknown contributions make it even more exciting to present to the English speaking public an assessment of her work. In Part I of this paper, Filippo Salvatore, examines her writing as an epic poet in the first part of the seventeenth century; in Part II Sr. Prudence Allen, considers her significance as a philosopher of the concept of woman at a crucial turning point in western intellectual history; finally, in Part III, Filippo Salvatore underlines Marinelli's significance as a political thinker.

\section{The life and works of Lucrezia Marinelli Vacca}

In the history of social and intellectual emancipation of women in European culture, Lucrezia Marinelli deserves a prominent place. Besides Christine de Pisan and Isabella d'Este, who preceded her, Marinelli is one of the outstanding learned women of the second part of the sixteenth century and the first part of the seventeenth. She was born in Venice in 1571 and died there in 1653 . She belongs to the Counter-Reformation, traditionally considered one the most troubled periods in Italian history. At this time, Italy was under Spanish domination, so lacked political liberty, and suffered under the strict censorship of the Catholic Church after the Council of Trent (15451563).

According to many critics the position of women in this period was worse than during the High Renaissance. Women such as Isabella d'Este at Ferrara or Elisabetta Gonzaga at Urbino played a significant role in the 
cultural and political life during the High Renaissance. The relative freedom enjoyed by women belonging to the middle and upper classes came under attack and in its stead misogynous writings flourished. A scholar like Ginevra Conti Odorisio still adheres to the widely held belief that "Seventeenth century misogyny is to be viewed within the general framework that emerged in Italy with the Counter Reformation... and a negative judgement, at least as far as women are concerned, cannot be modified. After the Council of Trent woman became in the hands of the Jesuits an instrument of spiritual and civic servility". ${ }^{2}$

A more balanced view is expressed by Natalia Costa-Zalessow in her Scrittici italiane dal XIII al XX secolo: "According to many critics", she writes, "the position of woman got worse, and as a result there were no outstanding woman writers. And yet, if one looks closer, one realizes that this view is not entirely exact. In the last decade of the 16th century and in the 17th century, feminism became militant through the pen of Modesta da Pozzo, Lucrezia Marinelli and Suor Arcangela (Elena) Tarabotti". ${ }^{3}$

Misogynous literature in this period is particularly violent. Woman is treated as a synonym of every possible sin and the embodiment of a devilish nature. One tragic side of this intolerant conception of womanhood are the notorious witch hunts of the sixteenth century. ${ }^{4}$ One of the most vicious attacks on women is Giuseppe Passi's Donneschi Diffetti published in Milan in 1595. It is as a reply to Passi's book that in 1600 Lucrezia Marinelli published La nobiltà et l'eccellenza delle donne co'diffetti et mancamenti de gli huomini. ${ }^{5}$

Besides Lucrezia Marinelli other women writers, such as Moderata Fonte, Arcangela Tarabotti and Sara Copia Sullam were active in Venice at the turn of the seventeenth century. The Queen of the Adriatic was one of the places where feminist literature sprang forth. Venice had been for centuries a place where a secular approach to life had been allowed to flourish and where a more democratic form of government existed. ${ }^{6}$ The University of Padua allowed Protestants like William Harvey to register, and it was at Padua that Pomponazzi discussed the immortality of the soul, Andreas Vesalius dissected corpses, and Galileo Galilei defended the heliocentric conception of the universe. Padua was one of the places in Catholic Europe where freedom of thought was allowed and where great strides were made in medicine, philosophy and physics. ${ }^{7}$

This is the cultural and social background that has to be kept in mind if we are to understand how Lucrezia Marinelli was able to publish her treatise. In addition, Marinelli's father was particularly interested in women's issues, 
and so her home environment predisposed her to being aware of the long line of significant women writers from Padua and Verona who had preceded her. She was well aware of Cassandra Fedele, Isotta Nogarola and others who formed her gender specific cultural background.

Lucrezia Marinelli was the daughter of a physician, Giovanni Marinelli, who came from the city of Modena. He was an admirer of Aristotle, and he had a good library to which Lucrezia had access. She probably attended the frequent gatherings, so typical of the time, where literary, philosophical and medical topics were discussed. That she was present is attested to by the fact that Lucio Scarano praises her at the beginning of his text for the impact that her poetry and rhetoric had made upon him in one of these gatherings.

Giovanni Marinelli had a keen interest in the condition of women and published Ornamenti delle donne in Venice in 1562, and Le medicine pertinenti alle infermità delle donne in $1574 .{ }^{8}$ Lucrezia's brother Curzio followed in his father's footsteps and became himself a physician. Lucrezia began to write around the age of twenty and her first work, La Colomba Sacra, was published in 1595. It is an heroic poem in ottava rima on the life of the young and beautiful Christian Colomba who preferred to be a martyr rather than abandon her faith to become the wife of the emperor Aurelian. ${ }^{9}$ Two years later in 1597 Marinelli published Vita del Serafico et Glorioso San Francesco. This biography of Saint Francis was later included in a collection on Saint Francis edited by Father Silvestro da Poppi in $1606 .{ }^{10}$

Other works by Marinelli that deal with religious topics are: La Vita di Maria Vergine, Imperatrice dell'Universo (1602, reprinted 1610 and 1617); Vita di Santa Giustina (1606); Vita de'Dodeci Heroi di Christo et de'Quattro Evangelisti (1617); De Gesti Heroici e della Vita Meravigliosa della Serafica S. Caterina da Siena (1624) Le Vittorie de Francesco il Serafico (1644); Rime Sacre (1603). She also wrote in ottava rima summaries of Luigi Tansillo's Le Lacrime di San Pietro (1606, reprinted 1738). ${ }^{11}$

Lucrezia Marinelli dealt also with mythological and allegorical topics in her writings. In 1605 she published the Arcadia Felice and, in 1618, the Amore innamorato ed impazzato. This poem echoes Ariosto's masterpiece Orlando Furioso and Angelo Poliziano's Stanze per la Giostra, especially in the description of Iridio's hunt, a young man who does not care about love and whom Cupid wishes to wound. Several of Marinelli's love poems are part of the collection Rime delle signore Lucrezia Marinelli, Veronica Gambara ed Isabella della Morra, con l'aggiunta di quelle di Maria Selvaggia Borghini, published in Naples in 1693. 
Lucrezia Marinelli's reputation and claim to fame rests on two other works. The first is La nobiltà e l'eccellenza delle donne co'diffetti et mancamenti de gli huomini which appeared in Venice in 1600 and was reprinted three more times with additions and corrections. It is a landmark at the European level from a philosophical and a sociological point of view for it exemplifies a keen understanding of the social forces that kept women in low esteem and dire dependency on men. These will be discussed in the second part of this essay.

The other work that brought her fame as a poet is Enrico ovvero Bisanzio Acquistato, published in 1635 and later in 1844 and in $1845 .{ }^{12}$ Enrico is an epic poem in 27 cantos in ottava rima. ${ }^{13}$ The topic, as was customary after Torquato Tasso's Gerusalemme liberata, is based upon an historical event, Venice's conquest of Byzantium during the fourth crusade (1202-1204). ${ }^{14}$ The major characters, Dandolo himself, Baudoin Count of Flanders, Boniface, Marquis of Monferrato, Louis, Count of Blois, and Isaac and Alexis Commenus, the legitimate heir and the usurper of the throne of Byzantium are real. Others like the female warrior Claudia, the magician Eson, and the knights Venier, Rainiero and Giacinto are the product of Marinelli's imagination. The combination of 'historia e favoloso', taken from the Christian tradition rather than from the pagan mythology, is recommended by Tasso. Marinelli is a follower of Tasso, like that other great lady of early seventeenth century Italian letters Margherita Sarrocchi, author of La Scanderbeide (1623), an epic poem that deals with the heroic resistance of George Castriota, surnamed Scanderberg (the Great Alexander), against the Turkish invasion of Albania in the later part of the fifteenth century. ${ }^{15}$ Marinelli is also sharply aware of the debates on the nature of epic poetry presented by Aristotle in his Poetics. In her letter to the readers of the Enrico she clarifies her stance:

I have, in order to render worthy of heroic majesty my poem, followed what Aristotle writes in his poetics, although I did not venture too far from Homer's teachings, for he was labelled as a living and true idea of heroic poetry. And If I imitated the moderns in some instances, one can see, if one analyzes the intent, that I took as true sources the Greek and Roman poetry, and will find out that primis gratiae sunt habendae. ${ }^{16}$

Marinelli points out that she developed only one major plot, even though some minor ones are linked to it, in order to respect the canon of the diversity within unity that Aristotle refers to when he speaks of an animal perfect in each of its parts. 
In the history of the emancipation of woman, Lucrezia Marinelli occupies an important position. She is more important than the better known Dutch author Anna Maria van Schurman or the French writer Marie de Gournay, the adoptive daughter of Montaigne. But does Marinelli deserve still the fame she enjoyed in her lifetime as a great poet? In the 1844 edition, the editor points out that the reader will find in the Enrico

some sharp traits, appropriate comparisons, and sometimes prominence and worth in the plot. In a word he will notice that if Lucrezia had lived in a better age, her talent would have merited even in our times a conspicuous amount of praise. ${ }^{17}$

This view corresponds to the notion that seventeenth-century Italy was a period of decadence especially in literature where Giambattista Marino had dazzled his contemporaries with his pomposity and his frivolity. ${ }^{18}$ For Monsignor A. Della Chiesa, a contemporary of Marinelli, however, she

was an admirable woman for her eloquence and wisdom, who in composing verses has risen so high that I believe there is no one that can match her. ${ }^{19}$

Benedetto Croce expressed a nuanced view of Sarrocchi and Marinelli as epic poets:

Sarrocchi was a correct writer who belonged to a good tradition; a hint of her literary taste very little 'marinesco' is her comment to Della Casa's rhymes. But, the principal of the women writers of epic poems was the Venetian Lucrezia Marinelli who wrote Enrico, ovvero Bisanzio acquistato (1635). In general it has to be noticed that the women writers were rather conservative, and avoided almost completely using conceits and baroque argutezze, which seemed to require some kind of virility. If one cannot find in the works of seventeenth century female writers true poetry, one can, nonetheless, find movements and feminine voices and the expression of feelings, but it is rather rare to find even in them a spirit of real humanity. ${ }^{20}$

A recent critic, Costa-Zalessow, has this to say about Marinelli's worth as a poet:

Lucrezia had an easygoing hand, but her verses are not very profound, even though they are correct and elegant. As I said she was the greatest writer of epic poems, but her art owes too much to her models: Poliziano, Ariosto, and above all Tasso. Nonetheless I have to admit that a serious study of her literary production is still lacking and ought to take into 
account the predominant taste of early Seicento and her own temperament as an emancipated woman. ${ }^{21}$

We feel that Marinelli's epic poem Enrico is a major work of art. She combines epic and chivalrous elements and her models are not only Ariosto or Tasso but Homer and Virgil. The setting, Byzantium, allows her to make frequent references to ancient Greek culture, and her heroes Venier, Rainiero and Giacinto, resemble more Achilles and Hector than Rinaldo and Orlando. The female character of Claudia is not just an imitation of Tasso's Clorinda. Claudia is the expression of the attributes bestowed in La nobiltà on the legendary Amazons and Valasca, the friend of the Queen of Bohemia, who, "possessing a generous and great heart, scorned that a man could command to her". Enrico Dandolo, the main character of the poem, is not idealized as much as Godfrey of Bouillon, the commander in chief of the crusaders in Tasso's Gerusalemme liberata. Dandolo remains a strong, sharply drawn human figure. He is described as Christ's warrior who chastised tyrants. Marinelli upholds the cause of justice and reveals the base motives that moved Alexis Commenus to usurp the throne. Honor and justice, much more than love, are the dominant feelings in Enrico which is more epic in tone than Tasso's Gerusalemme. The choice of one of Venice's most glorious historical pages enables Marinelli to express her deep love for her native city. Enrico is often a pretext to give vent to her patriotism, exactly as Luis de Camoes had done in The Lusiads.

Enrico deserves an important place in the genre of epic poetry, both within the Italian and the European tradition. ${ }^{22}$ In addition, Marinelli fills the ideal of an intellectual from the period by being versed in many fields: philosophy, literature, music. She was one of the first women to teach in public in Venice, and she was well aware of Cassandra Fedele (1465-1558) who "disputò pubblicamente" and who had preceded her. ${ }^{23}$

Marinelli married late in her life, around the age of 50 to Girolamo Vacca after 1625 . Her family name was Marinella, and was so spelled early on in her career as a writer. It became Marinelli and, after her marriage, she was referred to as Marinelli Vacca. Lucrezia Marinelli lived a long and fruitful life, and died at the age of 82 on October 9, 1653 in Venice where she always lived. She was buried in the Church of San Pantaleone. 


\section{Marinelli and Theories of Sex Identity}

Lucrezia Marinelli's La nobiltà et l'eccellenza delle donne co'diffetti et mancamenti de gli huomini, when placed in an historical context of works on the identity of woman, is remarkable both for its breadth and depth of philosophical argumentation. ${ }^{24}$ Indeed, it is the first major text written either by a man or a woman which is completely devoted to the fundamental theories about woman's identity which had been proposed by previous philosophers.

The earliest theory of sex identity, or sex unity, was first articulated by Plato (c. 423-355 B.C.) in Republic and Laws. ${ }^{25}$ It claims basically that there are no philosophically significant differences between the sexes, and that woman and man are equal in dignity and worth. This view re-emerged in Renaissance platonism with the specific implication that a woman could reason as well as a man. In Renaissance commentaries on love, there are frequent references to Diotima, the teacher of Socrates, in the Symposium. This supported the claim that a woman could be a philosopher as competently as a man. ${ }^{26}$

The second theory of sex identity that formed a background for Marinelli's work, is sex polarity, and was first formulated by Aristotle (384-322 B.C.). ${ }^{27}$ In this theory woman was considered to be an imperfect man, to have a biological defect which led to a weakness of mind, and to a difference in virtue. The Aristotelian theory concludes that there are philosophically significant differences between the sexes, and that the male is naturally superior to the female. This tradition did not support women philosophers or even the capacity of women to exercise discursive reasoning.

A third theory, sex complementarity, was developed in medieval Christian philosophy. Although it was hinted at by Augustine (354-430) and Anselm (1033-1109), its first philosophical defense was provided by Hildegard of Bingen (1098-1179) in Causae et Curae. ${ }^{28}$ In this view, man and woman are equal in dignity and worth, but there are philosophically significant differences between the sexes. Hildegard's arguments develop an elaborate typology (based upon a medieval theory of humors and elements) of four different kinds of men and women. The use of discursive reason by both men and women is encouraged as a fundamental component of wisdom.

Lucrezia Marinelli developed the first completely philosophical rationale for a fourth theory of sex identity, namely reverse sex polarity. In this view it is argued that there are philosophically significant differences between 
the sexes but, in a reversal of the traditional Aristotelian claim for male superiority, a defense of female superiority is found. Reverse sex polarity was first suggested by Henry Cornelius Agrippa (1486-1536) in On the Superiority of Woman over Man. in 1529.29 Marinelli's several hundred page manuscript goes far beyond the short text of Agrippa in its support of female superiority. She argues directly against Aristotle's theory of woman's identity, repeatedly invokes Plato's theory to defend the equality of the sexes, demonstrates that she was well aware of works by previous women philosophers such as Hildegard, and develops her own rationale to defend the superiority of woman over man.

Marinelli's philosophical approach to woman did not appear in an intellectual vacuum; she was partly the product of centuries of discussion about woman's identity by Italian authors. The earliest record of women engaging in discursive reasoning about the subject of woman is found in texts written by men which were either promoted by or dedicated to women. Guido Cavalcanti's (1255-1300) Canzone d'amore, or Donna mi prega was written in direct response to a woman's philosophical questions about the nature and essence of love. ${ }^{30}$ Leonardo Bruni D’Arezzo's (1388-1444) De Studiis et Literis, was written for Battista di Montefeltro about woman's need to study ethics and, in particular, the writings of Epicurus, Xenophon, and Aristotle. ${ }^{31}$

The next step in the association of woman with discursive reasoning occurred in the writings of men who began to include female participants in philosophical dialogues. Petrarch (1303-1374) used a female figure 'Laura' in the Triumphs and in the Canzoniere entitled "Rime in vita e morte di Madonna Laura" to act as a guide, who taught him how to use reason to conquer overwhelming emotions. ${ }^{32}$ This model followed that of Lady Philosophy in Boethius's (480-524) well known The Consolation of Philosophy.

Giovanni Boccaccio (1313-137.5) used a female figure, 'Fiammetta,' in Filocolo to represent his view that reason ought to order the instincts. In the Decameron, seven female figures are on an equal footing with male characters in exchange of ideas, arguments, and anecdotes. In Concerning Famous Women, Boccaccio records many examples of the "keen intelligence" and "intellectual power" of women, a human characteristic that goes beyond gender. ${ }^{33}$ It should be pointed out in passing, however, that while Marinelli did not mention these writings of Boccaccio, she chose to ignore them, possibly because of their condemnation by the Church. Instead, she focused on the Corbaccio or The labyrinth of love, which presented the sex polarity view, or a devaluation of woman. It is this latter derogatory view of women 
that is most often associated with the writings of Boccaccio, although in our view Boccaccio's contribution to the history of woman's identity is more complex than this. ${ }^{34}$ In the Decameron and Concerning Famous Women he frequently portrays women as out-thinking and out-acting men in a playfully competitive environment.

After the revival of neo-Platonism by Marsilio Ficino (1433-1499) and the reintroduction of Socrates' teacher, Diotima, in his commentary on Plato's Symposium, the presentation in dialogues of a female disputant who teaches a male how to exercise his discursive reason becomes even more prevalent. ${ }^{35}$ Although Marinelli and most scholars interpret Leone Ebreo's (1460-c.1521) views on women to be within the sex polarity tradition, it is interesting to note nonetheless that in the Dialoghi d'amore the female figure 'Sophia', the personification of mature wisdom, guided her young male student "Philo', the embodiment of youthful passion, towards a deeper understanding of philosophical love. The dialogue abounds in the exercise of discursive reasoning in long and sustained debate. ${ }^{36} \mathrm{By}$ the phrase 'discursive reasoning' is meant a sequential argument using fundamental principles of logic. Ebreo, through the dialogue of Sophia, creates a model of feminine character who excels in discursive reasoning and rational argumentation.

Other examples of later Renaissance dialogues in which female figures direct the debate can be found in Raffaella by Alessandro Piccolomini (1508-1578), La Leonora by Giuseppe Betussi (1523-1560), and the Dialogo d'amore and La nobiltà della donna by Ludovico Domenichi (1515-1564). ${ }^{37}$ It is sometimes claimed that ideal women in the writings of men did not have much effect on the situation of real women. We would argue, however, that these texts, in which female figures were used to represent the highest level of discursive reasoning, fostered an atmosphere in which women were more and more accepted as capable of philosophical disputation.

It is within this context that the next increase of philosophical texts about women's identity occurred. In The Book of the Courtier by Baldasar Castiglione (1478-1529), extensive arguments were given against the Aristotelian claim of the inferiority of woman. A character named Giuliano de'Medici concluded his critique of the Aristotelian Gasparo: “...women can understand all the things men can understand and...the intellect of a woman can penetrate wherever a man's can." The conversations in this dialogue are reputed to be a report of actual discussions which took place at the home of the Duchess Elizabetta in Urbino. ${ }^{38}$ It should be pointed out that some critics understand Castiglione's contribution to discussions of gender to be ambiguous at the least or destructive of woman's identity in other ways. ${ }^{39}$ 
However, when approaching women's history from the perspective of philosophical argumentation about women's capacity to reason, Castiglione stands out as being among the first to place in a dialogue a character who offers extensive arguments to support the view that women were capable of the highest rational thought. Therefore, in this way he helped to prepare the way for women who actually manifested this characteristic.

In a similar way, Pietro Bembo (1470-1547) recorded in Gli Asolani philosophical conversations between four men and three women which were based on actual debates that took place in the court of Caterina, Queen of Cyprus and Lady of Asolo. Gismondo, one of the disputants, states clearly that the female disputants should intervene as often as they please, "these discussions are no more ours than yours." Madame Berenice replies: "I shall feel free to blaze a trail for my companions." 40

Other Renaissance writers, who directly supported woman's use of reason, were Maffeo Vegio (1407-1458) who in De Educatione Liberorum Clarisque Eorum Moribus wrote about the education of girls; Jacopo Filippo Foresti (1434-1520), who described women philosophers in De Claris Mulieribus and De Illustribus Foeminis opusculum, and Pompeo Colonna (1479-1532) who in Apologiae Mulierum libri II rejected Aristotle's arguments for women's inferiority, invoked Petrarch and Plato in women's defense, and mentioned several women philosophers by name. ${ }^{41}$

Other Renaissance authors took the contrary position and argued forcefully that women should not be educated to exercise their discursive reason. Angelo Pandolfini (1360-1446) in Il Trattato del governo della famiglia, Francesco Barbaro (1390-1454) in De Re Uxoria and Leone Battista Alberti (1405-1472) in I libri della famiglia all argued that women ought not to be given access to books. ${ }^{42}$ However, for the most part, the overwhelming strength of the argument of Renaissance male writers about women's identity was on the side of those who supported woman's development of discursive reasoning, and who particularly encouraged direct exchange of ideas and arguments between women and men. In this way Lucrezia Marinelli's work can be seen as the outcome of a preparation which had preceded her for two hundred years.

The final important factor prior to Marinelli's extraordinary achievements was the growing number of writings by women themselves. The earliest women writer about woman's identity with roots in Italy was Christine de Pisan (1364-1431), who wrote The Book of the City of Ladies, The Book of Three Virtues, and Mutacion de Fortune. She was one of the leading figures in the "querelle des femmes" which took various positions about 
whether the Le Roman de la Rose devalued women intellectually and morally or whether it was simply a literary work without gender or religious overtones. In one text, she says: "To the best of my knowledge, no matter how long I confronted or dissected the problem, I could not see or realize how their claims could be true when compared to the natural behavior and character of women." 43 Lucrezia Marinelli used precisely this strategy to prove her own theory of the superiority of women.

The next significant woman philosopher to consider woman's identity was Isotta Nogarola da Verona (1418-1466). A prolific writer of letters, Nogarola also penned a philosophical dialogue De Pari aut Evae atque Adae Peccato in which she treated Aristotle's sex polarity arguments with irony. By applying Aristotle's biological justification of the inferiority of woman to the question of original sin, she concluded by a reductio ad absurdum that Eve's sin was less serious than Adam's. Nogarola often used Aristotle to reach an ironic conclusion. For example, she concludes that Eve is less guilty for the original sin because her nature is weaker. Some critics interpret this method as "flawed" because it seems to imply that Isotta accepted the premise that woman was weaker. ${ }^{44} \mathrm{We}$, on the other hand, believe that she was intentionally ironic in this argument, and that she used Aristotle's premise of women's weakness to demonstrate that it led to a reductio ad absurdum. Lucrezia Marinelli mentions Isotta Nogarola several times. ${ }^{45}$

Many other women of the Italian Renaissance engaged in philosophical debate with men. Cassandra Fedele (1465-1558), Vittoria Colonna (14901547), and Veronica Gambara (1485-1550) all gave evidence of philosophical reasoning in their correspondence. ${ }^{46}$ Marinelli knows them all and she mentions them in her text. Isabella Sforza (Rossi) (1471-1524) wrote Della vera tranquillità dell'animo in which she supports a stoical orientation while referring to Socrates, Plato, and Plotinus. Tullia d'Aragona (1506-1565) wrote Della infinità d'amore in which a female figure, Tullia, led a discussion about the nature of love. In both of these cases the women integrate their own views with those of their predecessors. ${ }^{47}$

Men began to first dedicate their works to women, next they included women figures in their philosophical dialogues, and then they began to attack Aristotelian arguments which limited woman's capacity to enter into philosophical discussion. Finally women writers began to reflect on their own experience and to write directly about sex identity. When Lucrezia Marinelli wrote La nobiltà et l'eccellenza delle donne, she was continuing a trend that had already been firmly established within the Italian Renaissance. It needs to be pointed out that she was fully aware of other Venetian women who had 
been prominent in the humanities; she mentions Laura Veronese, Veronica da Gambara, and Ginevra Veronese. She appreciates in particular Isotta Nogarola also from Verona, who "was adorned with philosophical doctrine," who led a philosopher's life and was satisfied with very little - she wrote to popes Nicholas and Pius and she remained a virgin; and Cassandra Fedele "who was very learned, held public disputations in Padua and wrote an elegant book on the order of science and composed very beautiful lyrical verses." 48 She also marvels at the extensive knowledge of Marguerite de Navarre and Lucrezia d'Este, Duchess of Urbino, in philosophy, literature and sacred letters.

Marinelli's own work is superior in breadth and depth to anything that had been previously written on the subject. It set a new standard and raised the level of debate about women to a higher level. We will now turn to a detailed examination of her own text. Because Marinelli's work is not available in English, extensive passages will be included to enable the reader to gain a first hand experience of her remarkable style and the rich content of her thought.

\section{La Nobiltà et Eccellenza delle Donne}

Earlier in this paper four different theories of sex identity were distinguished: sex polarity, sex unity, sex complementarity, and reverse sex polarity. Lucrezia Marinelli was a strong proponent of reverse sex polarity, that is, she attempted to prove that there are significant differences between men and women, and that women are by nature superior to men. The full translation of her lengthy title makes this purpose clear:

The Nobility and Excellence of Women with faults and shortcomings of men. Treatise by Lucrezia Marinelli, in two parts. In the first is presented the nobility of woman by means of irrefutable reasons and infinite examples and not only is Boccaccio's opinion destroyed but also both Tasso's, Speroni's, Bishop of Namour's, and Passi's but even the great Aristotle's. In the second is confirmed by means of true reasons and with many examples quoted from innumerable ancient and modern historians that men's faults supersede by far women's. ${ }^{49}$

Marinelli demonstrates her thesis from two different directions: first women's virtues are better and nobler than men's; secondly, men's faults are worse than women's. In the preamble, she restates her goals and identifies the philosophers she will defend and attack in this effort: 
In this treatise of mine ...I want to show that the feminine sex is nobler and more excellent than that of men (huomini), and I want this truth to shine in everyone's mind. And I hope to show this by means of reasons and examples that every man, even the stubborn ones, will be obliged to confirm with his own mouth. Plutarch came close to understanding this truth, as did Plato, in that great seventh dialogue of the Republic, and in many other books in which he demonstrates that women (donne) are nobler and more excellent than men (huomini). ${ }^{50}$

Marinelli identifies Plato and the neo-Platonists as the defenders of women against traditional sex polarity, but she goes beyond her sources when she claims that they argued that women were superior to men. Plato's argument simply defended the thesis that women were equal to men although he thought they were somewhat weaker, and he concluded that women ought to have equal access to education and to positions of authority in the state. Plutarch did suggest that women were sometimes braver and more courageous than men, but neither he or nor Plato defended reverse sex polarity.

Marinelli's preamble continues with a consideration of motives of previous writers about sex identity, and in it she identifies Aristotle as one of her main targets:

I am not moved by hate, wrath, or envy. On the contrary, these are all very far away from me because I have not wished, nor do I wish, nor will I ever wish, even if I lived at the time of Nestor, to be a male. However, I believe that wrath, hatred, or envy moved Aristotle in several of his works to speak maliciously against and to vituperate the womanly sex in the way that he blamed his master Plato in many other places. ${ }^{51}$

The core of Marinelli's argument is found in the first part of the text. There she enters into an examination of the premises of Aristotelian thinking which for so long had led to the dominance of the sex polarity theory. She also offers the first analysis of the etymological spectrum of the origin of the word 'woman'. She reveals a wide ranging acquaintance with many women philosophers such as Hildegard of Bingen, Hypatia, and Isotta Nogarola. She reveals a keen capacity for argumentation, and displays a sense of humor and wit that is very appealing to contemporary taste.

The first chapter shows how etymology and philosophy can be applied to the philosophy of woman's identity. Appealing to the authority of Aristotle who claimed, in the eighth book of the Metaphysics, that proper nouns reveal something of the nature and essence of things, Marinelli identifies five nouns that are particularly suited to comprehend the origin of 'woman': donna, 
femina, eva, isciah, and mulier. She argues that each of these nouns reveals a specific kind of superiority of woman over man. Donna "denotes lordship and power; but gentle power, or that which corresponds to the nature of the dominant person; because if she ruled as a tyrant, like uncourteous males do, perhaps the insolent detractors of this noble sex would be silenced;" 52 femina which is either derived from a [Latin] root 'fetu' that means 'production or generation' or a Greek root 'sos' that means 'fire', in either case, a sign of the greatness of woman. This is remarkable because within Aristotelian cosmology the male was always associate with generation or fire.

The third name of $e v a$ is traditionally explained as the source of life for all animated beings. Marinelli concludes: "..it [the feminine sex] is the one that gives being and life to males. What more can be said than to be able to give being and life? Therefore, this name goes beyond the other two because the first denotes lordship, the second production and fire, but this one life and soul, or the supreme perfection of all living things."53

In the analysis of 'isciah,' Marinelli introduces a Platonic model of the soul seeking union with heavenly forms. "This name denotes a celestial, divine and incorruptible fire whose nature is to perfect the soul entrapped in our bodies, to excite it, to teach it, and in sum to allow it to participate in divine perception removing from it all earthly ugliness." 54

Finally, in the analysis of the fifth noun applied to woman Marinelli takes to its logical conclusion a remark made by Aristotle himself: "The last noun is mulier, a Latin term which means 'soft and delicate' when applied to the body, but when applied to the soul means 'gentle and benign.' In either case woman is praised because a soft and delicate flesh reveals that the intellect of such a person understands more quickly than that of someone who has tough and hard flesh. This is what Aristotle teaches saying 'a soft flesh denotes a sharp mind.' "55

Marinelli concludes her etymological survey by setting it in a context in which the term 'woman' had often been used disparagingly. This becomes a pretext for a sharp affirmation of reverse sex polarity:

In my opinion all the nouns by means of which I have embellished this honored sex are, as I clearly proved, the most illustrious and lofty nouns that any human mouth could pronounce. Oh what rare and wonderful and praiseworthy nouns, for they denote and signify all the wonderful perfections that are to be found in this world. Any other noun has to yield to you, for you denote production and generation, fire, and splendor of the world, soul and life, divine and heavenly rays, gentleness and clemency, and finally lordship and power. Therefore, putting all these 
names in order one can conclude that woman produces the discourteous male, she gives him soul and life, she illuminates him with the splendor of divine light, she preserves him in his earthly appearance by means of warmth and light, makes him contrary to wild beasts, affable, courteous in his soul, and finally, rules over him by means of her pleasing and untyrannical power. ${ }^{56}$

In the second chapter Lucrezia turns to the "causes from which woman derive," and she identifies efficient and material causes as the focus of her analysis. Appealing to the chain of perfection in being (angels, men, animals) she argues that each kind of being is derived from a Platonic Idea or eternal exemplar in the mind of God. Leone Ebreo had called these ideas "divine precognitions of produced things", and Marinelli argues that the "Ideas of women are nobler than those of males, as their beauty and their virtue demonstrate." 57 Women are more beautiful and more virtuous than men, they have a greater perfection in a Platonic perspective where beauty and virtue rank very high on the scale of Ideas. She identifies the Ideas with the efficient cause. For the material cause, she argues: "...because a woman is made of a man's rib and a man made of mud she is nobler than he because the rib is nobler than mud." 58 As a result reverse sex polarity is supported by an appeal to what she calls both the efficient and material causes of woman and man.

In the third chapter the nature and essence of woman is examined. Equality between men and women derives from their being members of the same species and having, consequently, the same nature. Marinelli introduces degrees of perfection within the same species, and she argues that woman is more perfect than man from the moment of creation both in body and in soul. Her evidence is the greater beauty of the female body and the authority of many writers whom she quotes. She then appeals to Plotinus and to Marsilio Ficino to prove that a beautiful body is a consequence of beauty in the soul. This is why nature produces more females:

Nature, knowing the perfection of the feminine sex, produces women more abundantly than men, for nature always generates more of those things that are better and more perfect. And therefore it seems to be that Aristotle, against all reason and even against his own opinion that nature always aims towards the more perfect, believes that women are imperfect when compared with males. On the contrary, I would say that since nature produces a smaller number of males than women, that men are the less noble sex for nature does not wish to generate a large and abundant quantity. ${ }^{59}$ 
It is in the next chapter, that Marinelli ironically uses Aristotle to support her views of reverse sex polarity by stressing the logical implications of being an object of honor:

If women are the targets of honor they are nobler than males who honor them because the honored thing is always more worthwhile than he who honors it, for no one honors another individual if he does not acknowledge that he has some quality which is superior to himself as Aristotle himself says in the fourth book of the Ethics... Therefore, it is necessary to conclude that woman is nobler than man, because she is honored by him. ${ }^{60}$

Marinelli skillfully uses the adulatio perniciosa. She seems to praise Aristotle, only to criticize him more effectively by using his own words. ${ }^{61}$

Marinelli cleverly underlines Aristotle's apparent inconsistency in praising women in some places of his writings, while condemning them in others. By the end of the sixteenth century Aristotle's authority was being challenged. The moderns saw him as an easy target to attack. Galileo in the physical and Descartes in the philosophical domain later destroy an almost fanatical worship of the Peripatetics and Aristotle. Marinelli is certainly with the moderns. This explains her lack of reverence towards him and her addressing him in a familiar, witty manner, as in the following passage:

The good old fellow [Aristotle] also stated in the ninth book, chapter 1 of the History of Animals that women are more perspicacious and sagacious than males... However, not only are women more sagacious but also more shrewd than men, and he himself admitted it saying that "women are more shrewd than their husbands"...in the same chapter he uttered that women can be more easily deceived than males ... Not keeping in mind that just before he had said that they are shrewder and more sagacious and more insidious then men; all qualities that are contrary for the sagacious being deceived or trapped, and the shrewd can foretell another person's frauds. For man to be more sagacious than woman it would be necessary that he try to deceive a shrewd one who is one and a half times more shrewd. Demosthenes could not defend Aristotle from this error of his. But enough of him now. Let us put him aside. And I curse him. How many times does Plato celebrate women, in so many places? ${ }^{62}$

In order to appreciate Lucrezia Marinelli's sharpness, it is necessary to offer a more detailed analysis of her relation to Aristotle and his disciples.

In chapter vii of Part I Marinelli ponders the motives of her intellectual adversaries: 
It seems to me that I have clearly shown that women are nobler and more excellent than men. Now it remains for me to rebut the false objections of slanderers. They are of two types. Some of them are based on apparent reasons, and some others upon sheer authority and their own opinion. ${ }^{63}$

Referring to a story by Diogenes Laertius she suggests that Aristotle was motivated by envy of his wife, by inordinate self love, and by wrath towards the female sex in general:

These are the reasons that moved poor old Aristotle to claim that women are mendacious and chatterboxes, more envious and sharp tongued, and he did not realize that while he was saying that they were sharp tongued he himself became part of their number. In Book nine of the History of Animals, and in other passages, he claimed that they [women] are material, imperfect, weak, defective, and lighthearted, which I already spoke about in chapter iii. He could also be accused of taking the whole thing lightly, and he probably made a mistake about the nature and essence of women, [which was] likely too great a task for his small shoulders, not having maturely considered their nobility and excellence. ${ }^{64}$

Reprimanding Aristotle and others for generalizing from a particular example, Marinelli continues by examining some of his specific claims.

Her first argument focuses on the Aristotelian claim that the imperfection of the female is derived from the "fact" that males are hotter than females. Ironically, Marinelli accepts the Aristotelian premise, only to argue that heat is an imperfection.

Some claim like the good old Aristotle that women are less warm than men and are, therefore, less perfect and less noble. Oh what an indissoluble and omnipotent reason! I am convinced that Aristotle did not take into careful account the way warmth works, and what it means to be warmer and colder, and all the good and bad effects that are caused by it. For if he had thought it out well, he would have found out how many very bad operations that heat produces, and he would not have uttered a single word concerning [the warmth in men] which exceeds that of women. However, he went searching around like a blind urchin, and as a result he made a thousand mistakes. ${ }^{65}$

After mentioning that only certain degrees of warmth are good, she returns to Aristotle:

Therefore, Aristotle's reasoning does not have any value. Males are warmer than women, therefore, they are considered to be nobler in spite 
of the fact that we see that young people are not thought to be nobler than men who are in their middle age, and yet they [the young] are warmer. Not to mention the number of women who are by nature warmer than men. As a consequence one can not concede that Aristotle's statement is true when applied to all women. For there are many provinces, I will not say cities or castles, where women are by nature warmer than men of another province such as those of Spain and Africa who are warmer than the men who inhabit the cold northern climates and Germany. And how many do we believe were or are warmer by nature than Aristotle or Plato and are therefore nobler in their operation of soul? We shall conclude, therefore, in this way: that woman is less warm than man and as a result nobler, and that if any man who performs excellent deeds does it because he comes closest to the nature and temperature of women, for there is a placid and non-exceeding warmth in him, and that is why in middle age man the intensity of the warmth becomes more tepid than in youth, and coming closer to the feminine nature, he acts more wisely and maturely. ${ }^{66}$

Warmth by itself does not determine nobility. Rather moderation of warmth (which is closer to feminine nature) appears to reveal greater nobility. This argument is found in Hildegard of Bingen's work, although Marinelli did not cite her predecessor, and it is possible that she simply came to the same conclusion from similar premises. ${ }^{67}$

Marinelli often uses Plato as a foil to the sex polarity of Aristotle. While considering various virtues, Marinelli compares an unnamed disciple of Aristotle with Plato on the public and private spheres of activity:

Today you find few women who dedicate themselves to studies or to military art because men, fearing to lose their power and to become servants of women, forbid them from even learning how to read and write. That good friend of Aristotle claims that females must at all times and in all occasions obey males, and they must not seek to know about or participate in what is being done outside their household. [This is] a stupid and cruel sentence of a tyrannical and fearful man. Let us excuse him because, being a man, it was only natural that he would wish the greatness and superiority of men and not of women. However, Plato, that great man, [who was] in truth very just and far from imposed and violent domination, wished and ordained that women should take part in military art, in riding, and in wrestling and they should also go and give their opinion about the needs of the Republic. ${ }^{68}$

Marinelli quotes extensively from the Republic to support the claim she just made. Her first hand knowledge of the Platonic text is evident, and she also correctly understands the difference between Plato's support of the quality of 
women and men and the Aristotelian support for the superiority of men over women. She concludes her chapter with a rousing claim for reverse sex polarity:

God willing, how wonderful it would be if in our time and day women were allowed to exercise in arms and in letters. Wonderful things would be seen and unheard of both in maintaining and expanding kingdoms. And who would be a better shield than women to defend with their intrepid courage, and how quickly, and with such ardor, we would see them spill blood, and even life in defence of males. Women are much nobler in their activities than men; if they do not exercise, or if they do not partake in this, it is because they are forbidden by men who are being motivated by their obstinate ignorance being, as they are, cocksure that women are not good at learning. I would like such individuals to make this experiment: to exercise a boy and a girl of the same age and of the same good nature and talent in letters and arms. They would see in a very short time that the girl would much more quickly learn than the boy, and better, that she would beat him by a great margin ${ }^{69}$

In the following section Lucrezia Marinelli turns to history for the broad context of women thinkers. She moves away from traditional appeal to the Aristotelian or Platonic schools, and seeks a cohesive, intellectual framework within which to argue for the advancement of women scholars. Chapter vi is entitled: "Of Women Learned and Knowledgeable in Many Arts", and she begins by attacking those writers who through the centuries displayed a lack of knowledge of history when they were surprised to discover women who had been or were skilled in the arts, not only in ancient times, but also much closer to her own age. Famous women mentioned with particular relation to philosophy are: Aspasia ("most learned in philosophical studies"), Asottea ("disciple of Plato, [she] acquired great knowledge in the study of philosophy"), Hildegard of Germany (who wrote "very learnedly four books about natural causes"), Aretafila, Theano (who "wrote the commentary on the virtue of philosophy"), Hypatia (who "wrote some commentaries on astronomy), Heptatichia (who was "so famous in the study of philosophy that she succeeded Plotinus and she lectured in the very same school"), Triultia (orator and Greek and Latin scholar), Marguerite ("most learned in sacred letters"), Cassandra Fedele (who "gave public disputations in Padua and wrote an elegant book on the order of the sciences"), Lucretia da Este, Veronica of Gambara (who was "most exceptional in her writings"), Victoria Colonna, Isotta Nogarola ("who knew philosophical doctrines very well and 
who led a philosophical life.") ${ }^{70}$ These women constituted a source of inspiration and spurred Marinelli on as a women poet and philosopher.

Marinelli shows her biting wit and her frustration with the limited alternatives that were open to women at the time in the remaining long section of Chapter vi. She usually begins with identifying a particular virtue, and concludes with examples of well known women who embody each virtue. She lists fortitude, prudence, justice, magnificence, skill in military arts, tolerance, bodily strength, love for family, and love for their homeland as virtues in which women have excelled. These examples thus support concretely Marinelli's claim of reverse sex polarity.

At the beginning of the second part of the book in which the faults of men are identified and discussed, Marinelli returns to the Aristotelian argument about hot and cold. Males have greater heat, and this leads them to excess in their passions. She then hones her argument towards its consequence for sex identity:

All learned men are convinced that males are nobler than females because they are warmer by nature...I would add that it renders men unstable and inconsistent because "warmth shakes the body", and as Chalcidius says in his commentary on the Timaeus of Plato, "the soul is more mobile because of warmth". What great faults are those that spring from such a warmth that they praise and exalt so much, for because of it, the reasonable soul is bent and led astray from the right path of virtue, and allows itself to precipitate in dishonesty and lust out of which infinite other errors and enormous misdemeanors are born; this can not happen to the womanly sex, because being by nature warm and humid, their senses are ruled by reason. They are more temperate, more constant, more steadfast, more just, and more prudent than men. This happens because reasons stays in its own seat, which does not happen in the male, as I show with examples. How unhappy man would be if he had not the company of that rare gift which is a woman? Because I believe that one would not be able to find in the world a more crude and more horrendous monster than he is, nor a wilder and pitiless animal. But thanks to God woman restrains him, humbles him [and] renders him capable of reason and civil life. ${ }^{71}$

Marinelli sees the humidity of women as a restraining force on their natural heat. This allows for a greater balance in the female nature. In her defense of reverse sex polarity we find a reversal of Aristotelian sex polarity which claimed that women needed men to rule their inferior reason. The second part of the book gives examples of men who did not live virtuous lives. 
Marinelli examines the argument that men are nobler than women because they are "more robust, stronger, and better at carrying weight." She argues that if women were used to hard physical labor they would be as strong as men. Then, she turns the argument around, and claims that among men themselves greater physical strength is not always taken as a sign of nobility.

I do not believe that Aristotle, who defines women as being languid and similar to the left hand, was himself strong like peasants or many women are. He was then less noble than rough peasants and many women, and similarly blacksmiths would be nobler than kings or learned persons, which is completely unreasonable. ${ }^{72}$

The Pythagorean association of the female with the left and male with the right is ascribed to Aristotle by Marinelli, but Aristotle rejected this view. According to Marinelli, Plato showed "that there is absolutely no difference between the right hand and the well trained left". ${ }^{73}$

Marinelli gives many arguments against the Aristotelians derived from the theories of the Greek philosopher himself. However, she examines them in the works of more recent writers such as Ercole Tasso and Monseigneur Henri de Namour. Marinelli summarizes eight different arguments to prove that females are less noble than males:

Man is both an act and a form, he reasons better. Therefore, woman is the result of the worst part [misbegotten form]. The second is that everything that does not have its own end in itself is vile, and they are generated as a function of someone else. Such is woman who was created from man. Woman does not have in herself her own being because she received it from a man's rib. And therefore [she] is not a being. The fourth is: everything which comes to life against the intention of nature is a vice or a monster. Woman is a monster. The fifth is that woman is born because of a fault in the operating of nature like monsters who [are generated] by fault or superabundance of matter. Therefore, she is born by accident. The sixth is that every woman would like to be a man as an ugly person wants to be handsome and every stupid person learned. The seventh is that woman is particularly influenced by the moon. The eighth, women are usually humid and cold, and this is clear from the softness of their flesh and the size of their breasts. The ninth and last: laws exclude women from holding public office. ${ }^{74}$

Marinelli inveighs against the fourth argument, namely that woman is a monster: 
To the fourth I concede that those things which are born against the intention of nature are monsters and vice, but I deny strongly that women are born in such a way, first of all because monsters are seen rarely and are generated by nature. That is why we see many more women than men being born. Therefore, I say, that men are monsters for nature generates an abundance of what is better and a lesser quantity of what is worse. Besides nature's intent in the generation of the female is the same as that of the male if she wants to perpetuate the human species, because both the female and the male are required for generation. ${ }^{75}$

Even though Marinelli turns the Aristotelian argument around to prove that men, not women, are monsters, in the end she reaches a conclusion similar to that of Albert and Thomas Aquinas, namely that nature intends to produce both males and females. This view corrects Aristotle's original claim that in each conception nature intends to produce males, and that the female is a 'misbegotten or deformed male'.

In another section Lucrezia Marinelli considers the arguments of the peripatetic philosopher Sperone Speroni. She uses Aristotle himself to undermine the argument of his disciple who "in one of his dialogue entitled The Dignity and Nobility of Women tries to prove that women are born to serve man, and that they are generated by nature to do that, like those that are imperfect and impotent."76

Marinelli destroys this belief by simply denying that a woman is her husband's servant. She then corroborates her denial by appealing to the authority of Aristotle who had stated that a woman is a "companion" not a "servant" by nature and is therefore to be held in esteem, honour, even reverence by her husband. This equality between them is stressed even more by Aristotle in the Ethics, where he concludes that between husband and wife there has to be a sincere companionship, unanimous concord, and friendship which is not to be found between master and servant. Even when Aristotle in the Politics argues that the husband must exercise preeminence over his wife, Marinelli points out that this is but a civil power and "civil power is that of those who sometimes command and sometimes are commanded."77

After using Aristotle to defend her view that woman was not born to serve man, and that there should be a mutual service and companionship between husband and wife, Marinelli concludes with an ad hominem attack on Speroni:

Therefore, it is easy to see that Speroni's opinion is lacking those foundations which are true and real. Perhaps he went along with this 
opinion moved by the tyrannical insolence of many men who are being served not only by their wives, but by their mothers, and by their sisters with such a degree of vigilance and fear that with a lesser degree of fear do lowly servants and slaves serve their lords and masters. ${ }^{78}$

Marinelli uses this type of argument against other modern writers. She considers Torquato Tasso, the sixteenth century epic poet who, she claims, follows Aristotle and Thucydides in his views about women. Marinelli addresses each and every argument which range across themes such as physical strength, different virtues, and different intellectual powers. Although she argues that Tasso follows Aristotle, she uses Aristotle to defeat some of Tasso's views:

Concerning the distinction he makes between the virtues, the speculative ones being denied as proper to women, I do not agree with this supposition of his. On the contrary, women being of the same species as men and possessing one and the same kind of soul, and the same strength as all peripatetics state, and even Xenophon knew this and speaks about it in his Economicus where he says: "Virum fecit audaciorem mulier, memoriam vero, et intelligentiam dedit fratrem," I would say that speculation is as proper to a woman as it is for a man, but man does not allow a woman to spend her time for such contemplations fearing, with reason, her superiority. Similarly I deny that womanly prudence consists only in being obedient to her husband because Aristotle defines prudence, as "he who knows how to counsel to chose what is best regarding future things'; but who can deny that there have been many women in military government and also in government during peace, and that they have been very, very prudent? ${ }^{79}$

Marinelli's use of discursive reason extends also to Boccaccio's misogynist views expressed in his Corbaccio. She seems unaware of his more positive descriptions of women in other writings, especially in The Decameron. Marinelli begins by summarizing his various arguments against women. She then uses Aristotle's theories from the History of Animals, the Ethics, and the spurious Economics. She matches what she identifies as Boccaccio's views with strong observations of her own:

To destroy his false opinion I will say beginning from the beginning that woman are not imperfect animals, nor do they suffer from a thousand passions, except those that man's perverse nature makes them feel and produces in them every day. Woman does not want to be born a servant, for he who is by nature born a servant does not aspire to Lordship but he keeps on living in his native serfdom. One can say, therefore, that since 
women aspire to power they are not born servants but masters, as their very name of donna implies and demonstrates. ${ }^{80}$

Since his arguments bordered on satire, she answers him in kind:

Lastly, moved by anger he dares to claim that they are unshapely, ugly, and smelly, which is a most strange statement since their beauty a gift given to them by nature and by God... There is no greater cleanliness and tidiness in this world of ours than women's, since they hate messiness which renders their pretty bodies ugly, and all those things that emanate stinky odor. However, men being rougher creatures, are much more frequently untidy and dirty, as we can see. Some of them have much more grease and filth around their mustache and neck than cook cauldrons, and such a stench comes forth from their body that women who stand by them are obliged to plug their nose. I do not deny, however, that there are some women who are a little untidy, and a little unpleasant odor comes from them, like the woman who was loved by our urchin [Boccaccio], who since she was closer to her old age, and had eyes lacking a vivacious splendor, was constantly coughing, and was suffering from other faults typical of a senile age, and she was in truth a woman worthy of him. Boccaccio, may God have compassion on his soul, composed this book on the labyrinth out of anger and in a state moved by a very bitter affliction which brought him also to wish death. ${ }^{81}$

Marinelli's methodology matches that of her opponent. If he offers reasoned arguments, she provides the same. If he attacks in a satirical mode, she responds in the same tone of voice. Perhaps one of the most interesting aspects of her relation to Aristotle is the way in which she uses his own theories to prove her point in the second half of the book. Not only are women's virtues higher than men's, but vices are worse than women's. To show this, she uses Aristotelian definitions of vicious characteristics, and then she produces example upon example of men who were vicious. She uses Plutarch, Livy, Ovid, and Vergil as well as modern historians such as Tarcagnota, Giovio, and Botero, besides Dante and Petrarch. In addition she draws upon her own personal experience.

The numerous vices of men are considered in no less than thirty-five chapters. ${ }^{82}$ It is the first time in the history of Western thought that a woman offered so thorough a view of the faults of men. While there was a long tradition of literature, much of which was satirical, on the faults of women, the faults of men had received less publicity.

Lucrezia Marinelli is skilful in appealing to the appropriate historical, literary, and philosophical authority of her times. She accepts for the most 
part Aristotle's treatment of virtues and vices in The Ethics, but she uses Aristotle's general principles to refute his particular application of them.

Marinelli distinguishes between Aristotle's philosophy of the human being in general, and his philosophy of woman in particular. She recognizes the important contributions of Aristotle to philosophy, and affirms his importance. At the same time, however, she attacks his philosophy of woman, and as previously mentioned, is the first philosopher to give a thorough evaluation of this aspect of his thought. Her attack is not directed to Aristotle as a whole, but rather to an aspect of his thought that was clearly unsatisfactory.

\section{III}

\section{Marinelli's Political Thinking}

Lucrezia Marinelli's treatise On the Nobility and Excellence of Women deserves, for the reasons we have indicated, an important place in the history of thought about the concept of woman. Young when she wrote her treatise, (she was in her late twenties), she had not received a formal university education, for at the time and up to the first half of the eighteenth century Venetian women were not admitted in university.83 Marinelli had a knowledge of Greek, Roman, medieval and Renaissance culture as profound and extensive as the most learned humanists of her time. She quotes extensively from Dante, Petrarch, Boccaccio, Ariosto, Tasso, and numerous other fifteenth and sixteenth-century authors. She combines a love of poetry with the neo-Platonic philosophical tradition. She quotes with effect Plotinus, the Fathers of the Church, saint Augustine, Ficino, Leone Ebreo, and others. Her concept of womanhood is a skillful combination of her own time taken form the classical and Renaissance literary and philosophical traditions. She is convinced of the biological and intellectual superiority of women, and she proves her point. The reason why women do not enjoy the same social status and privileges as men is that they have systematically been denied the same rights.

Compared with more famous female writers, such as Vittoria Colonna, she has a better understanding of the social forces at play. Lyrical poetry is but one aspect of her work. She offers a sociological explanation of her own condition, and the role she can play. This is something unique. The typical woman was appreciated as a 'cortigiana', a singer or a noble woman. By contrast, Marinelli is a bourgeois and knows it. She refers to the way women from different social classes dress, behave, speak and think. From this point 
of view, Marinelli anticipates further developments. She knows that she is exceptional and frequently underlines the jealousy and narrow-mindedness women must bear. They are obliged to stay home and fulfill the whimsical wishes of their brothers and fathers, notwithstanding the fact that Venice at the time was the freest of the Catholic states. ${ }^{84}$

Venice was still at the intellectual avant-garde of Europe during Marinelli's life. The so-called decadence that affected the Italian peninsula became evident after Galileo's condemnation in 1633. In the first three decades, Venice, Florence, Naples, and Rome were still major cultural centers in Europe; John Milton travelled to Italy and imitated Della Casa and Tasso; Shakespeare borrowed from Giraldi Cinthio's short stories; Giordano Bruno influenced the English neo-Platonists at Oxford; and Giambattista Marino enjoyed an enormous success at the French court in the 1620's.

Lucrezia Marinelli is an exceptional figure, but she is also a product of her times. ${ }^{85}$ This can be seen when we look at her moral and political thought. A devout Catholic, she looks to Tacitus, the Jesuit Giovanni Botero, or the historian Tarcagnota for confirmation of her beliefs. This is evident in the second part of the treatise, where numerous examples of the moral corruption and evil behaviour of men are taken from the late Roman Imperial period. The names of the emperors Nero and Caligula recur constantly and are the epitome of male wickedness. She considers that ethics and politics cannot be separated and refers to Botero's Della Ragion di Stato, a Catholic attempt to reconcile politics and morality.

Cesare Borgia, the new prince of Machiavelli, appears several time in her treatise, but atheist, Nicolo Machiavelli, is never mentioned because his works had been placed on the Index of Forbidden Books. Marinelli, like Ludovico Zuccolo or Scipione Ammirato, whom she quotes directly, is a typical 'tacitista.'

Marinelli's originality is manifest in the first part of her treatise. It is when she speaks about her own condition as a woman that she is most persuasive. Her resentment possesses intellectual strength and emotional intensity. She is clever at using sarcasm and irony. She frequently mocks Giuseppe Passi, who had written a book condemning women. Peripateticians, philosophers in books, people who are incapable of thinking for themselves, are also often the target of her wit. This is a trait of the baroque desire for novelty. The Renaissance ideal of 'imitatio' was being replaced by the concept of 'aemulatio.' The combination of 'imitatio' and 'aemulatio' engendered a process of 'creatio', the basis for the revolutionary concept of 'veritas filia temporis' which in turn led to the concept of 
linear progress. Marinelli's feminism can thus be inserted into the more global desire of the moderns to detach themselves from the ancients. Only in an age that praised and cultivated boldness and novelty could the centuries' old belief of women's inferiority be challenged.

The portrait that Marinelli paints of womanhood is complex, but it can be summarized in the words of 'donna onesta'. A woman has to be first of all a genuine female, that is, she must not deny her specific biological attributes. Marinelli believes that a woman's soft body and more pronounced beauty is a sign of her specificity and, in some ways, of her superiority over man. Endowed with these attributes by nature, woman has every right to care for or enhance her beauty. She quotes the Fathers of the Church to support a woman's right to dye her hair, render her countenance appealing, wear jewellery, and dress elegantly. ${ }^{86}$ Marinelli's approach to womanhood becomes more daring when it is a woman's intellectual capacity that is at stake. She is absolutely convinced that a woman has nothing to envy a man. In many instances women are intelligent and are sharper, although less strong physically than males.

She is able to rebut all the accusations that traditionally were made against women. First of all, she shows that women are not monsters because of their weaker bodily constitution. Using Platonic arguments she claims that the larger number of females and their shapelier form are, as we mentioned, an indication of their biological superiority. Concerning the accusation of women as querulous, chatterboxes, and vain, she can reply that men are as querulous and vain as women. For instance, she refers to the flashy attire 'alla spagnolesca' prevalent at the end of the sixteenth century. She often notices that some French men wear an earring, that Spaniards wear tight fitting trousers and jackets, and that Venetians pride themselves on embroidered and expensive collars. ${ }^{87}$

Women are less violent, less prone to betrayal, more respectful of religion, and more apt to keep their patrimony intact than men who squander a woman's dowry and ruin their household by gambling. Not one of the heretical sects was started by a woman. Venice was jealous of its independence but it remained a Catholic state, and Marinelli's arguments confirm this.

Marinelli cannot be reduced to a feminist, as G. Conti Odorisio has tried to do; if all of her works are taken into account, she is a much more complex figure. She is a defender of feminine identity, a good philosopher, a fine poet, an historian, a sharp observer of the contemporary scene, and a sincere Christian. She is an interesting example of the rich and complex cultural 
identity that could be found in Venice in the late sixteenth and early seventeenth century. ${ }^{88}$

\section{Concordia University}

\section{Notes}

1. Research for this article was supported by the Social Sciences and Humanities Research Council of Canada.

2. Ginevra Conti Odorisio, Donna e società nel Seicento (Roma: Bulzoni, 1979) 36. N.B. All translations from Italian critical sources, unless otherwise indicated, are our own.

3. Natalia Costa-Zalessow, Scrittici italiane dal XIII al XX secolo, testi e critica (Ravenna: Longo, 1981) 14. See also Emilio Zanette, Suor Arcangela Monaca del Seicento Veneziano (Venice and Rome: Istituto per la Collaborazione, 1960), ch. 3, 'La tirannia paterna' $83-112$; ch. 4 'L'inferno monacale' 113-178; ch. 6 'La polemica femministica' 211-238; and finally, ch. 11 'La semplicità ingannata' 411-446.

4. See, H.R. Trevor-Roper, The European Witch-Craze of the Sixteenth and Seventeenth Centuries and Other Essays (New York: Harper, 1967).

5. Giuseppe Passi, I Donneschi Diffetti, (Milano: Pontion, 1599). Concerning the 'devilish' nature of woman see, B. Tondi, La femina origine d'ogni male, overo Frine rimproverata, (Venezia, Brigonci, 1687). Another very critical book on women is by the German humanist Valens Acidalius, Disputatio Nova contra Mulieres, qua Probatur eas Homines non Esse (Frankfurt, 1595) See Costa-Zalessow, 139. According to Passi women have the following faults: they are "lusty, jealous, ambitious, adulterous, meretricious, and whores, shameless, witches, beautiful and therefore suspicious, light-hearted, quarrelsome, hypocritical, cowardly, hateful, thieves, sharp-tongued, chatter-boxes and simulators." See Conti-Odorisio, 37. Passi's book was expanded during twenty-three years in four different editions.

6. Giovanni Scarabello, Paolo Morachiello, Guida alla civiltà di Venezia (Milano: Mondadori, 1987) See especially the first part of the volume by Scarabello dealing with Venetian history. Conti Odorisio agrees that "compared with the reality of the other states in the Italian peninsula, the fact that only in Venice the analysis of the feminine condition reached so high a level, leads to the conclusion that the prerequisites for the formulation and the birth of such a topic, existed in the Venetian culture, even though it was not supported by concrete evidence which was extremely uncomfortable for women." (p. 47). Conti Odorisio is convinced that female writers, more than others, underlined the limitations of the belief in the myth of Venice as the perfect republic and as the worthy heir of ancient Rome. (p. 48). Contrary to this claim Lucrezia Marinelli is a strong supporter in the Enrico of the myth of Venice as the new Rome. In canto 16, stanzas 58-96 are a long panegyric of the excellence of Venice. The valiant knight Rainiero, while lying wounded in bed has a vision and sees St. Mark, the patron saint of the city...In stanzas 92 and 93 the praise of Venice is most evident... Marinelli underlines again in hyperbolic terms Venice's excellence in canto 22, stanzas 12-30. Erina describes this city to Venier from a chariot being drawn through the sky by winged horses... Marinelli was sixty-four when Enrico was published. Her belief in 
the preeminence of the Venetian constitution is the product of her mature thinking. Her civic pride is a form of patriotism comparable to Luis de Camoes' in The Lusiads. Conti Odorisio sees Marinelli only in terms of her feminism and does not therefore give a complete picture of her as a thinker and an epic poet.

7. Filippo Salvatore, Antichi e Moderni in Italia nel Seicento (Montreal: Guernica, 1987).

8. Patricia H. Labalme, "Venetian Women on Women: Three early Modern Feminists," Archivio Veneto, 117 (1981): 81-109, expands on Conti-Odorisio's book Donna e società nel Seicento insisting on "the particular Venetian ambience that contributed to this early manifestation of female feminism". On the role played by Giovanni Marinelli see, "Le discours de la médecine et de la science", by Evelyne Berriot-Salvatore in Histoire des femmes (XVIe-XVIIIe siècles), eds. Natalie Zemon Davis and Arlette Farge, Vol. 3 (Paris: Plon, 1991) 363-386.

9. Lucrezia Marinelli, La Colomba Sacra, poema heroico (Venezia: Giovan Battista Ciotti, 1595).

10. See Costa-Zalessow, 140.

11. Luigi Tansillo, La lacrime di San Pietro, poema sacro con gli argomenti, ed allegorie di Lucrezia Marinella ed un discorso di Tommaso Costo. Giuntavi in questa nuova edizione la raccolta delle sue rime notabilmente accresciuta (Venezia: F. Piacentini, 1738).

12. Lucrezia Marinelli, L'Enrico overo Bisantio acquistato, poema heroico (Venezia: G. Imberti, 1635), 647 pp.; L'Enrico, ovvero Bisanzio acquistato (Venezia: Guiseppe Antonelli, 1844). For a full bibliography on Lucrezia Marinelli, see the article in the Enciclopedia biografica e bibliografica italiana (Roma: Tasi, 1942), VI.II: 9-10.

13. Marinelli herself summarizes for the reader, at the beginning of her poem, the historical events.

14. Probably the best eye-witness account of the fourth crusade is the Histoire de la conquête de Constantinople by Geoffroy de Villehardouin. See Scarabello, Morachiello, 17-19.

15. The programmed novelty in lyric poetry in the Seicento is that by Giovanni Battista Marino: "the novelty of epic poetry is the one announced and indicated, proposed more than prepared, by Tasso. The structures and the themes of a long list of works in ottava rima repeat the Liberata, sometimes even in the plot and always in the topoi: a Christian knight lured by a perfidious temptress, love between heroes and heroines of opposite religions which ends up with the death in a duel, hell and heaven, angels and devils fighting each other, and a campaign of conquest with opposite armies and lofty pageantry. All writers more or less consciously, although praising this poet more than other ones, tread the same path opened by their teacher, but also feel more keenly their links with the classic models like Vergil and Homer and with the chivalrous poetry, with Orlando Furioso in particular." This is how a specialist of seventeenth-century poetry in Italy has assessed the relationship between Tasso and other epic poets, both male and female. It is a negative judgment which seems to preclude any form of originality. Cf. Claudio Varese, "Teatro, prosa, poesia" in Storia della letteratura italiana V, Il Seicento, (Milano: Garzanti, 1976) 700. 
16. L. Marinelli, L'Enrico, (Venezia: G. Imberti, 1635) 4.

17. Marinelli, viii.

18. An even stronger negative judgment of Marinelli's Enrico and in general of her poetry is given by E. Musatti in La Donna in Venezia, (Padova: Draghi, 1891) 134. Musatti is convinced that Marinelli "wrote according to the inelegant taste of the time and her poetry consequently is lacking good taste."

19. See F. A. Della Chiesa, Teatro delle donne letterate (Mondovì: Gissandi e Rossi, 1620) 214.

20. Benedetto Croce, "Donne letterate nel Seicento", Nuovi Saggi sul Seicento, (Bari: Laterza, 1934) 159-176.

21. Costa-Zalessow, 141.

22. For a critical appraisal of Marinelli's Enrico see A. Belloni, Gli epigoni della Gerusalemme Liberata (Padua: Draghi, 1893) 285-298.

23. Cassandra Fedele (Venice 1465-1558), was admired by Poliziano for her humanistic culture. She wrote in Italian and Latin Epistolae et Orationes (1589) and married the physician Gianmaria Mapelli. After she became a widow she retired in a convent in Venice where she died. Both Cassandra Fedele and Lucrezia Marinelli were, of course, exceptions. The rule at the time, both in Venice and the rest of Europe was to prevent women from studying. They were allowed to read only pious books. On this topic see, Janis Butler Holm, "The Myth of a Feminist Humanism: Thomas Saltter's The Mirror of Modestie," in Carole Levin and Jeanie Watson, eds. Ambiguous Realities (Detroit: Wayne State University Press), 197-218.

24. Lucrezia Marinelli, La nobiltà et l'eccellenza delle donne co'diffetti et mancamenti de gli huomini (Venezia: Gio. Batista Ciotti Sanese, 1601).

25. Plato, The Collected Dialogues of Plato, Including the Letters, Edith Hamilton and Huntington Cairns, eds. (New York: Pantheon Books, 1961).

26. For a detailed analysis of these theories see Prudence Allen, RSM, The Concept of Woman: The Aristotelian Revolution (750BC-1250AD) (Montreal and London: Eden Press, 1985) and "The Aristoteliam and Cartesian Revolutions in The Philosophy of Man and Woman”, Dialogue: Canadian Philosophical Review. XXVI.2, (Summer 1987): 203-281.

27. Aristotle, Politics, in The Basic Works of Aristotle, Richard McKeon, ed. (New York: Random House, 1941) 1260a 10-15.

28. Hildegard of Bingen, Causae et Curae in Patrologia (Paris: J. P. Minge, 1844-1904) Vol. 197. See also the German translation Heilkunde (Salzburg: Otto Muller Verlag, 1957), and Sr. Prudence Allen, RSM, "Hildegard's Philosophy of Sex Identity", in Thought, LXIV. 254, (September 1989) 231-241.

29. Henrich Cornelius Agrippa von Nettesheim, On the Superiority of Woman over Man, trans. Amaudin (New York: American News Company, 1873). For an analysis of texts on the superiority of woman over man see Conor Fahy, "Three Early Renaissance 
Treatises on Women", in Italian Studies, 11, (1956): 30-55. Please note that when a text has been translated into English and published, the English language title is used in this article.

30. Guido Cavalcanti, Canzone d'amore in Otto Bird, "Medieval Philosophical Thought as Reflected in the Canzone d'amore of Cavalcanti, according to the Commentary of Dino Del Barbo (Text and Commentary)" diss., U. of Toronto, 1939, 7.

31. Leonardo Bruni D'Arezzo, De Studiis et Literis in William Harrison Woodward, Vittorino da Feltre and other Humanist Educators (New York: Columbia University Bureau of Publications, no. 18, 1963).

32. Petrarch's Lyric Poems: The Rime Sparce and Other Lyrics, trans. Robert M. Durling (Cambridge Mass. and London, England: Harvard University Press, 1976): 64 and 556.

33. Giovanni Boccaccio, Thirteen Most Pleasant and Delectable Questions of love (Filocolo). Trans. Henry Carter (New York: Clarkson K. Potter, 1974) 91, 142; The Decameron, trans. Mark Musa and Peter Bondanella (New York and Scarborough: New American Library, 1982) 632; and Concerning Famous Women, trans. Guido A. Guarino (New Brunswick, New Jersey: Rutgers University Press, 1963) xxxvii.

34. For this view see Constance Jordan, "Boccaccio's Infamous Women: Gender and Civic Virtue in the De Mulieribus Claris" in Levin, Ambiguous Realities, 25-47. For Marinelli's comments see La nobiltà 22, and 47-8.

35. Marsilio Ficino Commentary on Plato's Symposium on Love, trans. Sears Jayne (Dallas: Spring Publications, 1985).

36. Leone Ebreo, "On Love and Desire: A Dialogue between Philo and Sophia", Renaissance Philosophy: Volume I: The Italian Philosophers, Arturo Fallico and Herman Shapiro, eds. (New York: Modern Library Edition, 1967) 172-3. Marinelli is critical of Ebreo herself; see, La Nobiltà 17, 350, and 362-3.

37. Alessandro Piccolomini, Raffaella: A Dialogue of the Fair Perfecting of Ladies, trans. J.N. (Glasgow: University Press, 1968); Giuseppe Betussi La Leonora in Trattati d'amore del Cinquecento (Bari: Gius. Laterza and Figli, 1912); and Lodovico Domenichi Dialoghi (Ferrara: Gabriel Giolito, 1621) and La Nobiltà della donne (Ferrara: Gabriel Giolito, 1551).

38. Baldasar Castiglione The Book of the Courtier, trans. Charles Singleton (Garden City, New York: Anchor Books, 1959) 213-4.

39. For example, Joan Kelly-Gadol argues that Castiglione is responsible for reinforcing the view that women ought to be subservient to men and entirely contained within the private sphere. She also points out that the female characters in the Courtier play a relatively minor role. See, "Did Women Have a Renaissance?" in Becoming Visible: Women in European History, edited by Renate Bridenthal and Claudia Koontz (Boston: Houghton Mifflin Company, 1977) 139-164.

40. Pietro Bembo, Gli Asolani (Bloomington: Indiana University Press, 1954) 22. For a fuller discussion of Bembo on this point see Margaret L. King, Venetian Humanism in an Age of Patrician Dominance (Princeton: Princeton University Press, 1986). 
41. Jacopo Filippo Foresti da Bergamo, De Claris Mulieribus (Paris: Colinaei, 1521); Maphaeus Vegius, Laudasis De Educatione Liberorum et Moribus Libri Sex in Sr. Maria Fanning, Catholic University Dissertation Series, Books I-III, 1933 and Sr. Anne Sullivan, Catholic University Dissertation Series, Books IV-VI, 1936; and Pompeo Colonna, Apologiae Mulierum libri II in Studi e ricerche sull'umanesimo italiano, Guglielmo Sappacosto, ed. (Bergamo: Ecc., 1972). See also Conor Fahy, "Three Early Renaissance Treatises on Women", Italian Studies, 11 (1956) 30-55. In addition to an analysis of De Laudibus Mulierum by Bartolomeo Gogio, De Mulierbus by Mario Equicola, and Defensio Mulierum by Agostino Strozzi, this article contains a bibliography of 41 works on the equality or superiority of women written or published in Italy during the fifteenth and sixteenth centuries.

42. Angelo Pandolfini Il trattato del governo della famiglia (Milan: Giuseppe Ripamonti Carpano, 1805); Francesco Barbaro De Re Uxoria, (Directions for Love and Marriage) (London: John Leigh in Fleetstreet, 1677); and Leone Battista Alberti I libri della famiglia in The Family in Renaissance Florence, trans. Renée Watkins (Columbia: University of South Carolina Press, 1969).

43. Christine de Pisan, The Book of the City of Ladies, trans. Earl Jeffrey Richards (New York: Persea Books, 1983), 3-4.

44. For this view see Margaret L. King, "The Religious Retreat of Isotta Nogarola (1418-1466): Sexism and Its Consequences in the Fifteenth Century", Signs: Journal of Women and Culture, vol. 3, no. 4 (1978) 807-822.

45. Isotae Nogarola Veronensis Opera Quae Supersunt Omnia (Budapest: Vindobonae apud Gerold et Socios, 1886), II, 228-231.

46. Cassandra Fidelis, Epistolae et orationes (Francifica Bolzettam, 1636); Vittoria Colonna, Gaspara Stampa, and Veronica Gambara in Rime di tre gentildonne del secolo XVI (Milano, 1930); Le più belle pagine di Gaspara Stampa, Vittoria Colonna, Veronica Gambara, Isabella Morra (Milano, Treves, 1935); and Rime e lettere di Veronica Gambara (Firenze: G. Barbera, 1879).

47. Isabella Sforza, Della vera tranquillità dell'animo (Roma: 1544); Tullia d'Aragona, "Della infinità d'amore" in Trattati d'amore del Cinquecento (Bari: Laterza, 1912).

48. Marinelli, La nobiltà 40-41.

49. Marinelli, La nobiltà: the title page of text. Translated by Filippo Salvatore as are all other passages from this text.

50. Marinelli, La nobiltà 1 .

51. Marinelli, La nobiltà 2.

52. Marinelli, La nobiltà 4 .

53. Marinelli, La nobiltà 6 .

54. Marinelli, La nobiltà 6 .

55. Marinelli, La nobiltà 8 . 
56. Marinelli, La nobiltà 8 .

57. Marinelli, La nobiltà 10.

58. Marinelli, La nobiltà 11 .

59. Marinelli, La nobiltà 23-24.

60. Marinelli, La nobiltà 25.

61. A case in point is a spurious text which was believed to be written by Aristotle during her time: "Aristotle himself gives several [examples of] the primacy of women even though he was their enemy and wanted to blame them; he gives diligence as their typical virtue...as one can see in book 1, chapter 3 of the Economics: "A woman is excellent at being faithful whereas a man is weaker." From these words one can understand how very wrong he was in other places where he claims that women are flighty and unstable, because diligence requires stability of mind and steadfastness." Marinelli, La nobiltà 25.

62. Marinelli, La nobiltà 28. There are long passages in Latin from Aristotle to support each claim that she makes. These have been deleted from the text.

63. Marinelli, La nobiltà 108.

64. Marinelli, La nobiltà 109-110.

65. Marinelli, La nobiltà 119.

66. Marinelli, La nobiltà 119.

67. On the topic of bodily warmth and its repercussions on gender see Ian Maclean, The Renaissance Notion of Woman (Cambridge: Cambridge University Press, 1980) in particular the chapter "Medicine, anatomy, physiology", 28-46.

68. Marinelli, La nobiltà 32-33.

69. Marinelli, La nobiltà 33 .

70. She also mentions the religious models of St. Brigit, Catherine of Siena, Catherine of Alexandria and concludes: "This shows what a little girl can learn if she sets aside the needle and cloth." Marinelli, La nobiltà 39-42.

71. Marinelli, La nobiltà 137.

72. Marinelli, La nobiltà 120 .

73. Marinelli, La nobiltà 129.

74. Marinelli, La nobiltà 121-122.

75. Marinelli, La nobiltà 123-124.

76. Marinelli, La nobiltà 126-127.

77. Marinelli, La nobiltà 126-127.

78. Marinelli, La nobiltà 127-128. 
79. Marinelli, La nobiltà 129-130.

80. Marinelli, La nobiltà 132.

81. Marinelli, La nobiltà 133.

82. The various vices of men are considered in chapters under the following headings: 1 ) avarice, 2) envy, 3) incontinence (including gluttons, drunkards, and generally unrestrained individuals), 4) wrathful, bizarre and beastly men, 5) the haughty and arrogant, 6) sloth, negligence, and daydreaming, 7) tyrannical men and usurpers of states, 8) men ambitious and lustful for glory, 9) vainglorious and bragging men, 10) cruel, unjust, and lethal men, 11) fraudulent, treacherous, perfidious, and perjurious men, 12) obstinate and stubborn men, 13) ungrateful and discourteous men, 14) inconstant and quick tempered men, 15) malicious men and those who easily hate others, 16) greedy men, thieves, assassins and pirates, 17) cowardly, fearful, and vile men, 18) blasphemers and despisers of God, 19) incantors, magicians, and soothsayers, 20) mendacious men and liars, 21) jealous men, 22) ornate, polished, embellished and bleached-haired men, 23) heretics and founders of sects, 24) men who are tearful and prone to weeping, 25) gamblers, 26) slanderers and false accusers, 27) talkative men and chatterboxes, 28) forgetful men, 29) men of little talent and fools, 30) men who killed their fathers, mothers, brothers, sisters and nephews, 31) men who killed their sons, 32) hypocrites and diviners, 33) seditious men and rioters, 34) ignorant and boorish men, and 35 ) flatterers.

83. As far as we were able to ascertain the first public debate on whether women ought to be admitted to university in Italy took place in Padua at the Accademia de' Ricovrati in 1723. The various viewpoints were published in bookform in Padua in 1929 under the title Discorsi accademici intorno agli studi delle donne.

84. Excellent examples of this oppressive and patriarchal view of woman's social condition are Arcangela Tarabotti's works La semplicità, Lettere familiari de di complemento, and $L$ 'inferno monacale. On Tarabotti see Conti Odorisio, 79-113. See also Marinelli, La nobiltà, 262-263 where the same concept is expressed very strongly.

85. She was reared in a well-to-do household that praised and valued learning. Her father was a physician who was specifically interested in questions pertaining to women's condition and who befriended people like Lucio Scarano, himself a physician, philosopher, and professor at the University of Padua. Lucrezia grew up in an intellectually stimulating environment and she was treated and accepted as an equal of her brother Curzio not only by her father Giovanni, but also by his friends. Lucio Scarano had praised her for her poetic skills in "fino al cielo" in a public lecture held at the Libraria della Serenissima Dignoria di Venetia. It is upon Scarano's recommendation that the Consiglio dei Dieci, the executive branch of the Republic, gave its approval for publication of Lucrezia's treatise on women's nobility for in it "there is nothing against the laws and is worthy to be printed." Marinelli, La nobiltà imprimatur.

86. "Fathers of the Church did not condemn women completely when they adorned or made themselves beautiful. They blamed the excess of adornment which led to bad consequences. The wise Augustine writes in Letter 73 to the Poss. that married women are permitted to adorn themselves and to make themselves more beautiful with the intent to please only their husbands. Women are therefore allowed to beautify themselves and 
it is permitted by the Fathers of the Church to preserve their own beauty or to look prettier than they actually are as long as no error is engendered." Marinelli, La nobiltà, 264.

87. For some interesting details about the attitudes towards proper attire for men and the exuberant and flashy way of dressing by Venetian women see, P.J. Labalme, 94-96, 101.

88. With special thanks to Professor William Shea, McGill University, for his suggestions. 